\title{
Sustainable Urban Drainage Practices and Their Effects on Aquifer Recharge
}

\author{
Getrude Gichuhi and Stephen Gitahi
}

\section{Contents}

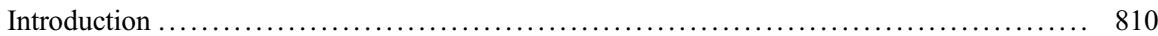

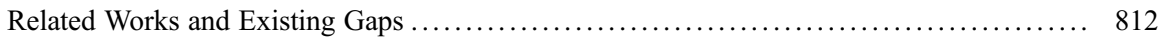

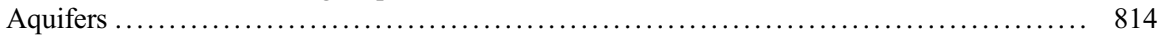

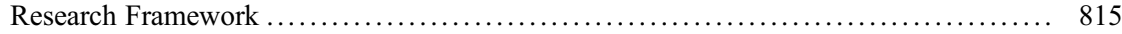

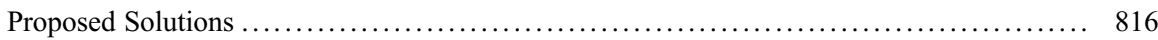

Substituting Alternative Water Source Control .............................. 817

Management of Aquifer Recharge ........................................ 820

Management of Discharge of Water ...................................... 824

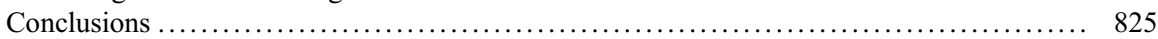

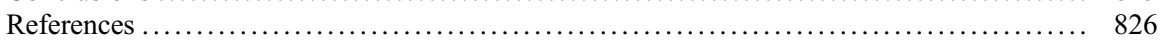

\section{Abstract}

Between 1994 and 2006, an 18\% increase of freshwater flow into the earth's ocean was recorded, as well as extreme weather events such as prolonged drought and intense floods. Following this period was an era of increased evaporation from oceans and seas, which heightened global warming in Africa. This chapter proposes the use of man-made aquifers recharge processes as methods of draining water into the soil before the runoff water reaches water bodies. Source control involves controlling the volume of water entering drainage systems or rivers by cutting off runoff water through storing for reuse or evapotranspiration as seen in green roofs. Pre-treatment is the use of trenches to filter and remove

This chapter was previously published non-open access with exclusive rights reserved by the Publisher. It has been changed retrospectively to open access under a CC BY 4.0 license and the copyright holder is "The Author(s)". For further details, please see the license information at the end of the chapter.

G. Gichuhi $(\bowtie) \cdot$ S. Gitahi

Department of Research and Innovation, Strathmore University, Nairobi, Kenya

e-mail: ggichuhi@strathmore.edu; stephen.gitahi716@strathmore.edu 
contaminants from water before getting to water bodies. Retention systems on the other hand is controlling the rate at which water is discharged to waterways by providing water storage areas such as ponds, water retention areas, etc., while Infiltration Systems are areas that allow natural soaking of stormwater runoff to the ground naturally recharging the water table. The proposed methods will see replenishing of the water table, a great leap in the efforts of curbing global warming. This practice can easily be adopted by both individuals and government as we build more and more buildings creating a balance between the need for human settlement and the natural way of water replenishing itself. The methods do not introduce extra costs to an already existing budget. In some cases, the methods help to reduce the costs of projects especially in urban areas. Africa which hosts many of the growing countries sees and will continue to experience surges in urbanization. For such, these methods presented in this topic will be, if implemented, a best method to solve the urban drainage problems before this even occurs.

\section{Keywords}

Aquifer · Hygiene and sanitation - Groundwater recharge - Global warming · Urban water balance $\cdot$ Universal water security $\cdot$ Topographical land

\section{Introduction}

Since 1990, water rise in the sea and oceans has been recorded and is now more visible than any other time in human history (The Ocean Portal Team 2018). The highest attributed factor has been melting of glaciers on ice topped mountains and concrete constructions. This ice melts and flows as runoff water into small water collection points such as ponds and swamps to bigger water bodies such as rivers, lakes and oceans increasing water flow into water bodies. All these changes result in an increased global water cycle where water moves cycles through evaporation, precipitation, and runoff, an aftermath of increased rate of global warming.

Methods of mitigating the negative effects of climate change in Africa have become a big issue. Individual companies and governments in Africa are trying to implement resilient ways that adapt to the effects of climate change. African countries are prone to the effects of climate change especially because of the higher levels of industrialization. On the other hand, developed countries that have implemented ways of harnessing water and avoiding runoff water directly to catchment areas at all costs is something Africa has not been able to fully accomplish (The United Nations-Water 2015). According to a report by UNEP, by 2020, between 75 million to around 200 million people in the African continent are projected to experience water stress due to climate change (UN Environment Programme 2020). In this twenty-first century, most countries in Africa are becoming urbanized; modern housing, infrastructure, access to water, and implementation of technology has become common (Ogwu 2019). Narrowing down to East Africa, Kenya is the 
most urbanized country and then followed by Rwanda. Cities are evolving and the idea of implementing sustainable urban drainage is still an issue as they improve the topography of cities.

Kenya's fastest growing cities include Nairobi, Mombasa, Thika, Machakos, Nakuru, Malindi, and Kisumu. Untapped but identified as potentially stable upcoming cities include, Tatu city and Konza city. This research identifies these two areas as the best place to promote sustainable urban drainage (SUD) systems and aquifer recharge is implemented. Other cities will follow the example set by these two as the benefits come to play. The total population for Kenya currently is at 54 million, according to the 2019 census; Nairobi, the capital city has just over four million people (Kenya Data Portal 2019). Water Security in a country is one of the major issues facing each country worldwide. According to Sustainable Water Partnership, water security is the adaptive capacity to safeguard the sustainable availability of, access to, and safe use of an adequate, reliable, and resilient quantity and quality of water for health, livelihoods, ecosystems, and productive economies (Viala 2016). UN Water defines water security as the ability of a community to protect their sustainable ways of accessing quality water (UN Water 2013). This is very vital especially to areas that have a huge population. Insufficient water in some areas is caused by drying up of the aquifers, while some areas are faced with excess water either due to flash floods, or rainwater runoff, which in turn leads to less aquifer recharge. These imbalances are a clear result of insufficient aquifer recharge. With no improved strategies to better ways of harnessing water, especially with the current climate projections showing irregular weather patterns, aridity of these cities is prone to increase at a very high rate. A case point is Two Rivers Phase II project, a modern residential center hosting a mall in Nairobi and Kiambu Counties in Kenya, which if the runoff water is not taken care of, the drying up of aquifers might kick off. Water in Two Rivers in which the development seats are likely to rise. Coastal areas are also facing similar issues. A case of concern there is salty water finding its way into the water table recharging the aquifers and thus making the water for consumption saline.

Rural-Urban transformation has improved the topography of most countries in Africa. Although, this has culminated in the improvement of settlement areas as well as the economic status of residents, it has heightened developmental challenges such as making water runoff move to a collection base settled in one area, which either flows to other big catchment areas or slowly evaporates. This chapter aims to put more emphasis on ensuring that sustainable urban drainage systems are implemented in a bid to see that boreholes that source water from aquifers are managed responsibly ensuring water availability and safety. Africa has not yet formulated the policy of adapting the best practices of sustainable urban drainage systems and natural aquifer recharge methods. Aridity of land, increase of saline water, drying up of aquifers, and increased water wastage, especially with increased upcoming constructions, are an indication of the state of globalization and effects of climate change in a country. Sustainable Urban Drainage Systems are drainage networks that act as collection points, transport, treat, retain, infiltrate and drain runoff water in sustainable ways that are beneficial for living things and the world in general (Hidrologia 
Sostenible n.d.). Given this background, the aim of this chapter is to review the status of sustainable urban drainage and Aquifer recharge within African context, highlighting some technological advances to be used in the current scientific and topographical challenges of climate change.

\section{Related Works and Existing Gaps}

This chapter uses referencing points, of developed countries, and how they implemented the SUDs, which affects the natural recharge of Aquifers. According to Matos (2003), drainage systems are not necessarily a rule when it comes to construction of infrastructures, and runoff water would cause flooding of the roads or clogging of the sewers. On the other hand, Tim (2008) speaks of the Christian era, where drainage systems constructed by the Romans in the $\mathrm{BC}$ to $\mathrm{AD}$ are still functioning till date. Introduction of sanitation began in Italy after an incident of septic tank sinking due to floods and the country was forced to eliminate flooding areas and adapt underground channels, which was a wake-up call to other European countries in adapting sanitation systems (Poleto and Tassi 2012).

The use of green gardens in developed countries that substitute farming due to construction of buildings covering the whole land makes it necessary to adapt previous ways of MAR. An important agenda highlighted in this chapter is to understand how policies are followed to the latter for avoidance of implementing after math eqs. A study conducted in the United Kingdom regarding their technical, legal, and planning methods of control for urban runoff water in their country was done to ensure countries that do not have policies created to govern engineers before starting projects (Woods et al. 2015). Governance of Aquifers needs to be implemented. There are three aspects done in developed countries as to the governance of aquifers, management of discharge of water, management of recharge, and substituting alternative water sources.

Management of discharge of water from the aquifers currently is important as drawings from these sources are at a high rate, especially due to the domestic use of the water. Some countries use water mainly for commercial use while others use water to pump for electricity, irrigation and domestic use as well. As depletion of aquifers becomes more and more real, countries are forced to dig deeper boreholes with extra costs to incur to reach water levels (Dillo et al. 2011). These scenarios put more weight on the need to ensure recharge of the aquifers is managed well. Management of Recharge to the aquifers can be implemented both artificially and naturally. If $95 \%$ of the land is covered with soil and grass then the possibility of water sipping into the soil is most likely to happen faster reducing the amount of water that flows into water bodies. With increased urbanization, more innovative methods of recharging of aquifers are practiced by directing water to catchment bodies, and using filtration methods that enable water to be soaked into the soil and thus refilling the aquifers. Other alternative ways of using water sources include using rainwater and customizing it for consumption use. 
Due to urbanization, most countries experience a lot of runoff water, which therefore needs a number of managements of aquifer recharge procedures through identifying a number of solutions that gets back to the aquifers. These processes have been practiced before, and there is a need to introduce them in developing countries especially due to the increase of urbanization in these same countries. Use of permeable floors could be one of the implementing ways.

There are other substituting alternative water sources, which are currently used all over the world. Some authors have done research on how to tap water and collect it in a catchment where one can fetch for domestic use. Other water sources enhancements include channeling rain water through use of gutters, tapping water from a river into a house. More methods have been adapted in today's world to ensure that they have sources of water. Some negative points have been brought forward, such as some of these ways being harmful to the humans and the animals. A case study was carried out in Kilifi County in Kenya where the test was to find out the presence of arsenic in water and the $\mathrm{pH}$ of the same water. According to the World Health Organization (2003), $\mathrm{pH}$ of consumable water should be between 6.5 and 7.5.

A study research was done on SUDs in low-income countries in Africa outlining the disadvantages that runoff water instills such as soil erosion and siltation (Reed 2004). Some special cases have been raised, for instance, constructing riparian lands and coastal areas. These areas have a land mass that is not stable with fault lines that aid in the recharge of aquifers experience. Kenya has had cases of demolition of buildings due these buildings being on riparian lands, this was a threat not only to the SUDs not being observed but also to the lives of people who were meant to live and operate in such areas. Other concerns raised, is the groundwater overexploitation in the coastal regions and these buildings being on riparian lands. Groundwater overexploitation in the coastal regions leads to intrusion of salty water (Geiger 2020). This chapter will help us understand the options that a country has in case it is forced to build on riparian lands.

Some practices recommended in this chapter exist in developed countries and can be very effective in African countries in understanding climate change and how to deal with the effects of those changes. There are challenges facing the Kenyan topography such as cases of constructions being done on riparian lands. Such areas are not stable and could result in the collapse of such buildings. It has resulted in the government demolishing such houses and prosecuting responsible constructors for not adhering to the rules and policies that guide the said industry. Coastal lands on the other hand have cases of saline water recharging the aquifers, making it difficult for consumption especially to humans. The best result in these situations is to ensure filtration methods are used.

Policy making for engineers and owners is one of the proposals for governments to implement. Adaptive measures of some proposed solutions are suggested in order to ensure smooth implementation of SUDs and aquifer recharge as well. These include filtration methods and systems of reducing salinity and the productive measures of constructing buildings in riparian lands. Resolving these issues with the proposed methods will see an increase in the amount of water that goes back to the water table, replenishing it, as opposed to flowing into the ocean and seas. On a 
concrete surface, $95 \%$ of water on the surface runs off, only $5 \%$ gets absorbed into the soil. With natural aquifers taken into account in the landscape planning and designing, the $95 \%$ of the runoff water will be adsorbed to soil, resulting in only $5 \%$ of the water being drained to the oceans and seas. This mode of replenishing the water table ensures that wells and boreholes dug in arid and semi-arid areas do not dry up fast. The benefits of this extend to what such areas can do in their economic ventures and other activities made capable by the presence of stable water supply.

\section{Aquifers}

When Water soaks into the soils from the rivers, melted ices, and rain, it is concentrated in one area that forms its own settlement, which is referred to as an aquifer. This settlement of water is formed in different bowl-like areas that form a well and are all in different areas with different levels. A number of aquifers formed in one area are referred to as the water table level forming the zone underneath the ground. There are two types of aquifers, the confined aquifers and the unconfined aquifers. Confined aquifers are one that is way below almost at the bedrock of the rocks and formed by permeable rocks due to the pressure of non-permeable rocks. However, getting to the confined areas at times seems difficult and collapsing of the rocks could hinder reaching the aquifers when drilling boreholes. Unconfined aquifers are the ones that are directly refilled with the water soaking directly from the surface of rivers or when in a swampy area or irrigation is taking place. The unconfined aquifers are the ones that rise or drops depending on the amount of water stored.

Aquifers in rural areas and with a water source around are less tapped as compared to an arid area. In semi-arid areas where these boreholes are drilled with the changing weather conditions and less water source reservoirs, humans turned to aquifers, through drilling boreholes in pursuit of water. Sometimes the water turns to be saline, depending on the locality. For instance, coastal areas tend to have more saline aquifers as compared to fertile moisture soil with cold weather conditions. As urbanization in coastal areas increases, the drilling of boreholes is increasingly at a higher rate. This in turn, due to unconfined aquifers being empty, is refilled with saline water from the ocean. This is reusable, however not as drinkable water for humans nor animals as well.

Consistent use of these aquifers without recharges is only sustainable for a few decades. According to Kansas States University in Manhattan, a 4-year research of the Ogallala Aquifer was conducted to identify the use of aquifers for irrigation and consumption use in Kansa, they found out that continued use with no recharge could cause depletion of food production in that area (Chow 2013). Glaciers melting sorted that situation for a while with the chances of aquifer usage to be in survival for 50 years, after it only used up to $30 \%$ of the water.

Glacier melts in areas whose topographical land is associated with mountains and areas that are cold and can experience snow. Africa, has very minimal of such topography and therefore, a few proposed solutions on ways to manage the discharge 
of the water from the aquifers, how to recharge them and alternative ways of water use to avoid depletion of the groundwater.

\section{Research Framework}

Looking at the sustainable urban drainage practices that are done to the developed countries and the effects of aquifer recharge, there is an understanding that SUDs consideration will be established in Africa. With a different topography, there is a need for an analysis of the geographical area to determine any potential trends that are made or can be made. The analysis done is to determine a number of things, the risk factors involved in case an SUD is proposed in that area, and the number of SUDs to be implemented in that area, and the demographics as well. After analysis, the topographic area will help in determining the type of qualitative criteria to be used for the SUDs.

\begin{tabular}{|c|c|c|}
\hline Criteria & Relevance & Category \\
\hline $\begin{array}{l}\text { Guidance } \\
\text { documents }\end{array}$ & $\begin{array}{l}\text { These are the documents to be used } \\
\text { as the implementation process for } \\
\text { the SUDs in Africa. The use of these } \\
\text { documents either required by the } \\
\text { government or voluntarily offered to } \\
\text { the government by the implementing } \\
\text { partner shows the extent to which } \\
\text { the SUDs would have effects on the } \\
\text { aquifer recharge. These guidance } \\
\text { documents can be used as practices } \\
\text { that any organization or individual } \\
\text { looking into SUDs should have, and } \\
\text { also used as ways to overcome over } \\
\text { implementation of SUDs in one area }\end{array}$ & $\begin{array}{l}\text { Guidance documents not specified to } \\
\text { SUDs but to construction - Policy } \\
\text { constructions documents } \\
\text { Standard government guidance for a } \\
\text { country from the National } \\
\text { Construction Authority } \\
\text { Relevant government planning } \\
\text { policy statements concerned with } \\
\text { hydrology, and water as natural } \\
\text { resource, } \\
\text { e.g., a) delivering sustainable } \\
\text { development policy } \\
\text { b) Planning and pollution control } \\
\text { policy } \\
\text { c) Disaster and risk management } \\
\text { policy - This looks deeper into } \\
\text { drought and floods as ways of } \\
\text { managing disasters and risks in a } \\
\text { county }\end{array}$ \\
\hline $\begin{array}{l}\text { National } \\
\text { Construction } \\
\text { Authority } \\
\text { Consultation }\end{array}$ & $\begin{array}{l}\text { In order to ensure involvement, in } \\
\text { the case of Kenya, it is important to } \\
\text { ensure the National Construction } \\
\text { Authority is involved for assessing } \\
\text { the area, and the risk factors that } \\
\text { could be involved }\end{array}$ & $\begin{array}{l}\text { Consulting the National } \\
\text { Construction Authority of a country, } \\
\text { for location intelligence analysis, } \\
\text { through the use of documents, } \\
\text { records of previous assessments, } \\
\text { reports, and telephone and email } \\
\text { conversations. }\end{array}$ \\
\hline Constrains & $\begin{array}{l}\text { Financial constraints in case of a } \\
\text { collapse of a borehole drilled or a } \\
\text { pond created are some of the } \\
\text { constraints involved when it comes } \\
\text { to implementation of SUDs }\end{array}$ & $\begin{array}{l}\text { Other constraints could be through } \\
\text { desktop and site survey } \\
\text { CLA not specified and not included } \\
\text { in analysis due to no knowledge of } \\
\text { contamination at site. } 1 \text { - CLA } \\
\text { through desktop survey only. } 2 \text { - } \\
\text { Desktop and site survey }\end{array}$ \\
\hline
\end{tabular}




\begin{tabular}{|c|c|c|}
\hline Criteria & Relevance & Category \\
\hline SUDs type & $\begin{array}{l}\text { This chapter categorizes SUDs into } \\
\text { substituting alternative water } \\
\text { sources control, Management of } \\
\text { Aquifer recharge, and Management } \\
\text { of Discharge of water }\end{array}$ & $\begin{array}{l}\text { Substituting alternative water } \\
\text { sources control } \\
\text { (a) Green roofs } \\
\text { (b) Rainwater harvest } \\
\text { (c) Redirecting water retention } \\
\text { systems } \\
\text { Management of Aquifer Recharge } \\
\text { (a) Infiltration systems } \\
\text { (b) Treating municipal wastewater } \\
\text { (c) Treating storm water } \\
\text { (d) Treating irrigation water } \\
\text { Management of Discharge of } \\
\text { water } \\
\text { (a) Retention systems } \\
\text { (b) Wetlands }\end{array}$ \\
\hline Numbers & $\begin{array}{l}\text { Identifies current practice and } \\
\text { baseline data }\end{array}$ & $\begin{array}{l}\text { Types of SUDs to be used in that } \\
\text { area }\end{array}$ \\
\hline Size & $\begin{array}{l}\text { Identifies current practice and } \\
\text { baseline data }\end{array}$ & $\begin{array}{l}\text { How large or small will the SUDs be } \\
\text { used }\end{array}$ \\
\hline Efficiency & $\begin{array}{l}\text { Identifies current practice and } \\
\text { baseline data }\end{array}$ & How sustainable is the SUD used \\
\hline Maintenance & $\begin{array}{l}\text { Identifies current practice, baseline } \\
\text { data, potential barriers, ways to } \\
\text { overcome them, and trends }\end{array}$ & $\begin{array}{l}\text { How frequent should it be } \\
\text { maintained and treated }\end{array}$ \\
\hline Good practices & $\begin{array}{l}\text { Africa as a developing continent, } \\
\text { most of the topographical area is } \\
\text { improving day by day, which makes } \\
\text { runoff water become a potential } \\
\text { problem especially to rural areas. } \\
\text { Therefore, different mitigation } \\
\text { process of water should be } \\
\text { implemented in the policy making } \\
\text { and as part of construction when it } \\
\text { comes to buildings and roads }\end{array}$ & $\begin{array}{l}\text { Use of best practices. } \\
\text { Evidence of National Construction } \\
\text { Environmental Management Plan or } \\
\text { equivalent. }\end{array}$ \\
\hline
\end{tabular}

\section{Proposed Solutions}

On the account that there is uncertainty when it comes to climate change and the shortage of water especially in Africa, adaptation strategies on water usage and refilling of aquifers should be prioritized. Clear projections on water demands in the future are merely determined by the climate change, sustainability imbalances between freshwater, and demand for it (Taylor et al. 2009). There is a huge difference of climate change association in developed countries as compared to the developing countries. In addition, the fact that most countries in Africa are in the sub-Saharan desert, the usage of water is more likely to be at a higher demand and also depletes at a higher rate. 
Although, some of these solutions are implemented in other countries, recommending them to African countries, suits best especially during this time of globalization. African countries are known to be experiencing different kinds of weather conditions, as compared to developed countries. The Sub-Saharan desert covers most parts of Africa. Solutions proposed in this chapter targets what African countries would experience when it comes to recharge of aquifers as well as substitute water sources. Runoff water and the impact it has on climate change has the need of ensuring that the community is able to implement SUDs and redirect water to aquifers. This chapter discusses the methods to be used in African Countries in the management of discharge of water, management of recharge, and substituting alternative water sources.

\section{Substituting Alternative Water Source Control}

It is clear that using water from Aquifers is not only the one area that humans should depend on if it is for consumption at home or commercial level. There are other means of attaining water with source control implemented. Source control is a way of managing the volume of water entering drainage systems or catchment areas by cutting off runoff water either to be redirected into another source stored for reuse or evapotranspiration or to absorb into the soil as a way of recharging the aquifer (Geiger 2020). Mostly runoff water will be from rainwater, flash floods, or melting of glaciers. Besides, source control can be exercised when the water is settled in one area with no use of it. Wet areas are an example of how source control can be used.

A country's topography has around four features that affect how humans will cultivate and settle around that area (National parks Association n.d.). These are the landforms, which include the hills, valleys, gullies, and mountains, etc. These places act as animals settling places but as a tourist attraction to humans, which affects the economic status of a country. A water source is another feature of land topography, which mostly includes the rivers, swamps, coastal oceans, etc., which have a great impact on affecting our sources of water. Vegetation includes the national parks, the farmlands, etc., acting as the main source of food to both humans and animals. Manmade topographic features, which fall under the category that most humans ensure that they plough and invest in, comprises of buildings, roads, property boundaries etc.

The four features of land topography have a huge effect on aquifer recharge; the recharging of the aquifers depends on how much is interrupted. For instance, if the sources of water, rivers, swamps, oceans are polluted, the same water used to recharge the aquifers will reach the table water polluted which becomes harmful to human beings and animal consumption. On the other hand, if manmade features of the topography are not structured in a way that allows runoff water to seep back to the ground the possibility of the aquifer to recharge is of bare minimal. The untapped areas such as landforms and vegetation are most likely to have the water table to be fully recharged or at least for use through soil moisture and suitable for plantations. 


\section{Green Roofs}

The level of a city becoming smart has better ways of ensuring that it implements source control mechanisms. Green roofs are a way of turning barren landscapes into a living network of gardens (Willem 2005). It is a type of urban agriculture and a way of saving space and at the same time living expenses are reduced. Green roofs have a number of advantages such as:

(a) Reduction of runoff water - one of the main aspects that African Countries are trying to fight

(b) Act as a temperature buffer for the home. The plants combat the natural heat and coolness from the atmosphere

(c) Economical potential of cultivating food from the green roofs

Green roofs comprise a multilayered system that covers the roof of a building with vegetable landscaping. The roof is likely to consist of an impermeable layer, a growing medium, and a drainage layer. The impermeable layer aids in the survival of the plants by increasing the retention time of water in the substrate layer thus increasing the soil moisture. The Substrate layer or the growing medium layer retains the water and uses the right amount of organic and mineral proportions. The drainage system is the most important part in setting up the Green Garden. There are different types of drainage systems; however, the ideal one is that which provides good circulation and evacuation while at the same time offering water supply to the crops. In today's modern green garden drainage system, they use rigid and open mesh structures plastic sheets (Critical Concrete 2018).

Although, not to say that green roofs should be used in places where aquifer recharge is a priority, it only states that it can be used as an alternative source of acquiring water for consumption use and irrigation use as well. The implementation of Green roofs especially in urban areas of a country ensures hydrologic-hydraulic invariances in that area. This is one of the main areas that this chapter tries to focus.

\section{Rainwater Harvest}

Rainwater harvesting refers to different methods used to channel rainwater into an area where it can be used for other purposes (Black et al. 2012). There are various types of rain water harvesting systems used in different countries, which depends on the cost, size, and the complexity of the technology involved. However, the main aim is to ensure utilization of rainfall to be used as an alternative source of water both domestically and commercially. The beauty of it is that it can be used in a small or large industry or even at the homestead level. With the current climate changes, using resources to ensure the survival and usage of clean water in the future has been one of the ways to fight drought.

The collection of rainwater from rooftops, or other surfaces or even open space into a catchment area is known as rainwater harvesting. This harvested rainwater could be used commercially, domestically, or for farming purposes (irrigation). On the other hand, harvesting rainwater could act as an advantage by providing stormwater management especially in urban areas thus leading to detention pools, 
which are used to recharge aquifers. Slow runoff water has a higher chance of soaking into the ground, which has other advantages such as reducing contamination and avoidance of soil saturation.

The types of rainwater harvesting include:

1. Domestic rainwater harvesting. There are two types of harvesting systems used especially in developed countries: gravity systems and pump feed systems. Gravity systems are positioned at the top of a building, which uses gravity to propel water to different parts of the house. Examples are the use of gutters to direct water to the tanks. Pump feed systems on the other hand, is when water is pumped upward toward different water holding objects or tanks to be used for domestic use. Drilling of boreholes is an example of pump feed systems.

2. Commercial rainwater harvesting. There are different types of harvesting systems that are used in large farms. The most common one is water butts, which is one of the common harvesting systems used in the UK. Water butts are barrel-like or binlike tanks that collect water from drain pipes to store water that could be reused for farm use (The Renewable Energy Hub UK 2018).

Although, at times the collected water may not be user friendly, the level of treatment when it comes to harvested rainwater depends on the use required and the dimensions of the size of a home or industry. Water required for Aquifer Recharge will definitely undergo a strict way of treatment as compared to one used for irrigation purposes. Also, water required for human consumption will require strict treatment unlike farm use or irrigation; some TDS would be left in the water in order to give nutrients to the plants.

\section{Redirecting Water in Retention Systems}

Urbanization in today's world is more of covering all land with cement, leaving only the rural with soil. This significantly increases the runoff water to drainage systems, which are redirected to the rivers or other water catchments. In Rural areas the rate at which water soaks back to the soil and absorbed back to the soil is at around $95 \%$ as compared to an urban area, in which the water soaks only $5 \%$ that at least lands on soil, leaving only $95 \%$ running off. Urbanization in a retro sense has its effects on affecting water that flows. However, there are precautions that engineers can take when constructing buildings and roads.

In cases of riparian lands, as stated earlier in the two rivers case, policies and design ideas ought to be structured to ensure that water is not blocked. Water flowing rates, its magnitude, frequency, and duration should be part of the measures that are included when constructing in riparian lands. In addition, these features can determine at what rate and amount it will soak into the ground and down to the aquifers. Therefore, channelling the water and either use it is another means of source of water for commercial use or constructing measurable ways of ensuring that there is no runoff water. For swampy areas, at times the ground is too full to absorb more water and will result in flooding of homes, in this case there should be a channel that redirects where this water needs to be absorbed back to the ground in a land that is a bit semi-arid. 
Riparian land has been managed before using three practical methods, the Proper Functioning Condition (PFC), the Hydrogeomorphic Approach (HGM), and the index of Biological Integrity (IBI). In spite of the advancements in technology, African Countries have not yet implemented such strategies. PFC is a qualitative approach and depends on the knowledge and judgment of a team of experts. HGM and IBI on the other hand are based on quantitative data gathered and analyzed from unaltered to degraded sites prior to assessor's involvement (National Research Council 2002).

\section{Management of Aquifer Recharge}

\section{Infiltration Systems}

In the intent of refilling deep aquifers, a process involved, happens at a gradual rate through the unsaturated zone all the way to the aquifers. Although, there are underlying factors that depend whether the aquifer is suited in an area where it was used repeatedly then refilling it might take ages to do so. The creation of infiltration systems will look into a number of risk assessments, which include, land cover, soil characteristics, soil saturation, slope of the land, and evapotranspiration (Alley et al. 1999).

Dependency on water and the rate at which the water is used while it depletes in the aquifers depends on the population of a country; it is not only used by humans but also animals. Controlled ways of recharging the aquifers need to be implemented in order to ensure safety for the consumption of water. There are two ways of recharge, artificial recharge and Natural recharge. Artificial recharge is the process by which excess surface water is directed into the ground either by spreading on the surface, using recharge wells or altering natural conditions to increase infiltration. It is a way of storing water in case of a shortage.

There are a number of ways recharged water can be used. It can be redirected to semi-arid areas and arid areas for consumption and irrigation schemes. In coastal areas, with the use of artificial recharge, since it is fresh, this could be used as a control mechanism in avoiding seawater or saline water intrusion to the aquifers. There are three types of infiltration systems for aquifer recharge as a source of water, Treated Municipal Wastewater, Storm-water runoff, and irrigation water. In order to implement infiltration systems, risk assessments should be conducted by the government to ensure safety measures are in order. Infiltration systems largely influence ground stability and water quality as the latter flows to water streams. Examples of such systems are infiltration trenches, basins, and permeable paving.

\section{Treating Municipal Wastewater}

For the Municipal water of a country ensures that it treats and input infiltration systems there are a number of things they would consider. The quantity and quality of wastewater in an area, the commercial and industrial establishment off an area, and the condition of the sewer system. The municipality has to analyze the wastewater at their disposal and then run the ingredients they are to concentrate and 


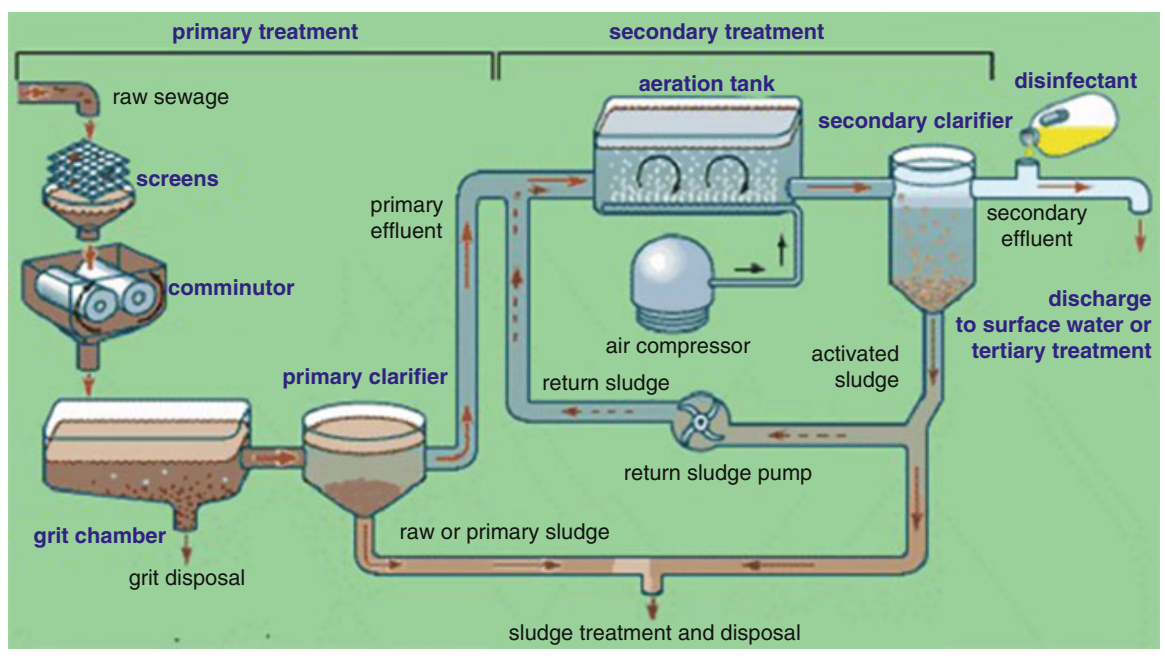

Fig. 1 Figure of the treatment process of Municipal Wastewater Infiltration process. (Eschool 2018).

dissolve. Untreated wastewater contains an amount of microorganisms' concentration. These factors include originality of the water used, the general health of the contribution population (are they in a slum area or in an urban area), and the infectious agents that survived outside the hosts under a variety of environmental conditions (The viruses, in a group become resistant to the environment that kills bacteria). Wastewater treatments are classified in primary, secondary and advanced level (Fig. 1).

The wastewater is first pumped to the system, and as a primary treatment, it is screened, then taken through to the grit chamber where the solid and huge particles are released, and finally to the secondary stage through the clarifier. The secondary treatment stage incorporates aeration process, which after takes the advanced treatment stage, which is the final stage before the water is directed to the aquifers for refilling or tanks for industrial or household use.

\section{a) Primary treatment of municipal wastewater}

This is the first step that includes screening of the state of the wastewater and grit removal. Once the water is screened, large solid particles are removed to avoid any interference at a late stage of treatment. Grit chambers are created as part of the infiltration systems to remove sand, seeds, glasses, eggshells, etc. There are other preliminary treatment operations such as the flocculation, odor control, chemical treatment, and pre-aeration. Primary treatment has very little effect when it comes to the removal of other biological species, which means it does not remove viruses at this stage

b) Secondary treatment of Municipal wastewater

This step is intended to remove soluble and colloidal biodegradable organic matter and other suspended solids (SS). This treatment involves an aerobic 
biological process whereby microorganisms oxidize organic matter in the wastewater.

\section{c) Advanced treatment of Municipal wastewater}

This is the third stage of removal of nutrients, for instance, phosphorus and nitrogen and SS. This is the physical, chemical, or biological treatment process used to accomplish a degree of treatment. It removes SS and dissolved substances either organic or inorganic in nature. This is necessary especially if there is a direct injection into the aquifers for recharge. The major processes in this stage include, coagulation-sedimentation, filtration, nitrification, denitrification, phosphorus removal, carbon adsorption, and reverse osmosis.

\section{Stormwater Runoff}

Stormwater runoff is one of the main contributors when it comes to aquifer recharge. However, pollution of the stormwater may contaminate the aquifers as well once they reach them, which needs treatment before they reach the aquifers. It is erratic in quantity and the timing as well could be when flash floods happen, or when a heavy rain has occurred. According to Larry, he tends to believe that season has a major impact when it comes to storm-water runoff quantity and the base flow (Mays 2001). The topography of an area has a major impact when it comes to stormwater pollution concentration, which tends to filter the pollutants. Impervious surfaces on driveways, parking areas, gutter drainage systems, and roads reduce infiltration of runoff and runoff to the ground.

Detention ponds are constructed for specifically recharging groundwater through the bottom of the pond. The water filters slowly through the ponds and to the aquifer, they are created deep enough to prevent water plant growth but shallow enough to prevent anaerobic conditions formed at the bottom. Inspection is necessary occasionally to ensure that treated water is what recharges the aquifers.

As a concept of salt evaporation ponds, water is directed into a pond where it is stored while it slowly soaks into the ground to the aquifers. In Kenya, Kitui District, Sand dams were created in order to store water, although this was only done in largescale farms. A sand dam is constructed as a small dam, in and onto a riverbed of a seasonal river, where it is accumulated with sand. The sand layer acts as a filter for removing contamination and enabling water to reach the aquifers and recharge them. With areas that frequently receive huge rainfalls, there are chances of groundwater levels being high considering the use of multiple sand dams.

Subsurface dams is another way of ensuring an aquifer recharge is exercised. They are created in semi-arid areas at the seasonal riverbanks, by digging a trench to the bedrock or other impervious layer. This is something that is exercised in Brazil and can be implemented in Kenya especially in semi-arid counties, such as Kilifi county. To prevent particles soaking into the ground, use of canvas when creating the trench is necessary to act as filters, which could puncture the fabric used.

\section{Treating Storm-Water}

Hydrogeologists ensure that they calculate the right places for constructions on ponds and measure input when it comes to treating the water to be used to refill 
Fig. 2 Figure of Filtration process for stormwater runoff (Fluence News Team 2017).

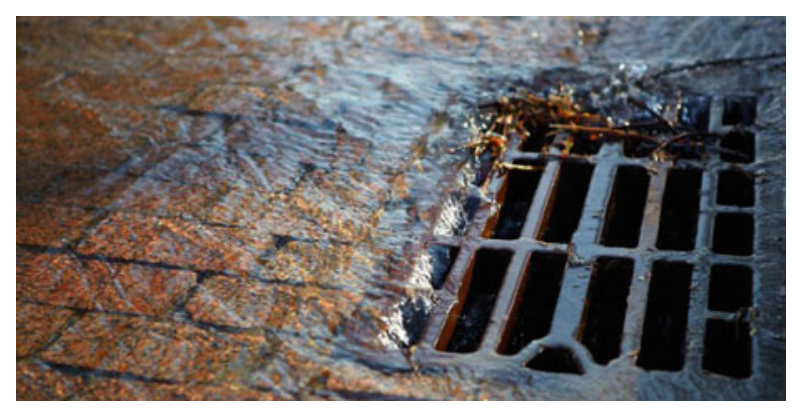

the aquifers, as well as calculating the right places that have aquifers that have enough water to be used. Sedimentation is the process of allowing suspended particles in water to settle out of the suspension under the effect of gravity. These particles become sludge, which is assisted by mechanical means that cause it to thicken (Bache and Gregory 2007).

Although removal of particles can vary from one version to the other, the variations of storm-water filtration may include vegetation filtration, drainage systems, and impervious pavements. The settlement of particles in ponds varies in different ponds in different areas. Therefore, when it comes to filtration either natural cause of treatment could occur when it comes to biodegradation, biotransformation, and bioaccumulation or the sedimentation process (Fig. 2).

\section{Irrigation Water}

Irrigation is considered one of the most important roles in food production in pursuit of food security of a country. Although exploitation of aquifer water for irrigation, and consumption use, particularly during dry season, has caused the groundwater level to decline in semi-arid and arid areas, there is no direct recharge of shallow aquifers. With the increasing use of groundwater, the rise of hydrogeological and climate change problems are becoming major setbacks of certain countries. However, Irrigation Return Flow (IRF) is a promising way of recharging the aquifers for better sustainability in the future.

Irrigation return flow is the excess drainage water collected from irrigated farmland, which is considered as not evapotranspiration or evacuated by surface water and is returned to the aquifer (Dewandel et al. 2008). Depending on the types of crops, there are likely to be a number of agricultural chemicals applied, with a varying range of quantity input to enable growth and avoid pests. Irrigation is mostly used in semi-arid and arid areas; this increases the salinity of the IRF to three times that of normal water.

\section{Treatment}

Numerous things are involved in the irrigation return flow water that includes TDS, nitrogen and phosphorous compounds, pesticides residues, and, at times, metallic substances. There are different kinds of technologies that have been implemented in 
different countries, especially with advanced technology, to ensure removal of such pollutants.

Reverse osmosis system is one of the technologies used; it is a process that uses a permeable membrane to remove TDS. The first step of reverse osmosis is the sediment filter. It is a polypropylene sediment pre-filter that removes SS from the water. Then the carbon granule filter is activated, which removes the chlorine and other organic substances, unpleasant color, tastes, and odors from the sediment water. The third stage is to activate the carbon block filter, which removes the remaining chlorine and organic substance without the carbon fines. The RO Membrane is the fourth stage that rejects the wide spectrum of impurities including bacteria and viruses. Finally, the polishing resin carbon filter dissolves gases to ensure freshness and natural tasting clean water (Hydrolink Technologies 2014).

Farm-led management is another implementation that most developed countries are undertaking. This involves training farmers on crop selection in relation to soils, methods of increasing yields, community-based pond water monitoring, and evaluation and knowledge management on aquifers. Besides that, training the farmers on the consequences of excessive use and implementation of well-directed aquifer protection measures has helped farmers to understand the quantity of water usage, fertilizers, and wastes to use.

\section{Management of Discharge of Water}

When water moves out of the saturated area or ground to the surface through springs or seeps, it is referred to as groundwater discharge. However, at times, groundwater discharge can be controlled, where water is pumped to a retaining tank or catchment basin. To ensure that water is used at a manageable rate, to avoid depletion of groundwater, control has to be instilled to ensure that this happens. There are various ways to ensure this happens, through creation of retention systems, existence of wetlands, and others.

\section{Retention Systems}

These are water systems meant to control the rate at which water is discharged to waterways by providing water storage areas such as ponds and small-scale basins. Retention systems are systems used to store water that is likely to be used for a longer period unlike detention systems that only store water for a short period and thereafter redirect filtered water back to the ground to refill the aquifers.

A case in point is, as the rainfall season approaches, seasonal rivers tend to overflow and at times cause flood in certain areas especially ones that are arid. In this case, building of retention systems to pump water from the river to the systems could help in the use of the water during dry seasons.

\section{Wetlands}

Another way that discharge of groundwater happens is through the existence of wetland areas. The riparian lands as well as the swampy areas are in balance due to 
the discharge of the groundwater. Though wetlands also come with various benefits of ensuring that the soil is hydric and at the same time maintaining the ecosystems habitant in these areas, the increase of groundwater discharge to springs and streams dampens the amplitude of flow fluctuations thus sustaining associated wetland environments. As a control mechanism, artificial wetlands are best ways to mitigate stormwater runoff issues.

\section{Conclusions}

This chapter recommends the smart infrastructure management methods and mitigation of rainwater and runoff through practices that direct water to catchment areas with a purpose of meeting the needs of saving water and utilization of water especially for African Countries. The focus on African countries is due to some falling under dry regions which means the possibilities of these countries being faced with reduction of water in the 50 years from now would be high in case they do not observe the different methods of mitigating water. Besides, the use of these mitigation processes has socioeconomic impacts, which include the reduction of negative impacts of disaster risk management such as floods and drought on social life and reduction of energy costs, which is economical to a country.

Most countries in Africa are currently adapting the advanced technologies such as Internet of Things (IoT), and Artificial Intelligence, either, in their cities, homes, or work environments. Implementation of MAR with such technologies has a likelihood of ensuring quality, and sufficient water for most African countries, thus improving the country's economic status. The main agenda is to ensure that we avoid urban flooding in African Countries, with the implementation of infrastructures that help in redirecting runoff water to refill aquifers when already treated. This chapter suggested a number of solutions such as permeable pavements, implementation of green roofs, retention systems, rainwater harvesting methods, and use of catchment areas.

Policy-making guidelines is another way to direct constructors on how to implement certain measures when constructing a structure that could distract water flow to reach the aquifers when treated and safe. Use of these guidelines ensures to incorporate the decision making and avoid constraints such as environmental constraints (instability) and financial constraints (more expenses in water treatments and retention systems).

Water harvesting and other techniques have been used to help preserve water before runoff, the use of man-made aquifer recharge methods as a form of SUDs is a natural and more efficient way of helping runoff water to seep back to the water table and ensure a balance. This allows the table to follow its natural way of seeping in between permeable rocks from saturated to unsaturated areas. While trying to curb global warming, this is a step toward managing the effects of the melting ice caps through the natural replenishing of the water table. This practice can easily be adopted by everyone as we build more and more buildings creating a balance between the need for human settlement and the natural way of water replenishing itself. 


\section{References}

Alley W, Reilly TE, Franke OL (1999) Sustainability of ground-water resources. CIR. U.S.Dept of the Interior. U.S Geological Survey. https://doi.org/10.3133/cir1186

Bache DH, Gregory R (2007) Flocs in water treatment. The International Water Association Publishing

Black J, Maimbo M, Oduor A, Cherogony K, Meerman K (2012) Rainwater harvesting inventory of Kenya. An overview of techniques, sustainability factor and stakeholders. https://doi.org/10. $13140 / 2.1 .2299 .5208$

Chow D (2013) Water woes: vast US aquifer is being tapped out. Live Science. Retrieved from https://www.livescience.com/39186-kansas-aquifer-water-depletion.html

Critical Concrete (2018, December 18) Retrieved from critical concrete website: https:// criticalconcrete.com/green-roof/

Dewandel B, Ganolfi JM, De Condappa D, Ahmad S (2008) An efficient methodology for estimating irrigation return flow coefficients of irrigated crops at watershed and seasonal scale. Web of Science Core Collection 22(11):1700-1712. https://doi.org/10.1002/hyp.6738

Dillo P, Enrique F, Albert T (2011) Management of aquifer recharge and discharge processes and aquifer storage Equilibrium. Thematic Paper

Eschool (2018) Wastewater treatment types. Retrieved from https://eschool.iaspaper.net/ wastewater-treatment-facts/wastewater-treatment-types/

Fluence News Team (2017, May 8) Fluence. Retrieved from Fluence: https://www.fluencecorp. com/what-is-stormwater/

Geiger WF (2020) Sustainable water management chance for mega cities in developing countries. In: International symposium on new directions in urban water management

Hidrologia Sostenible (n.d.) Hidrologia sostenible. Retrieved from Hidrologia Sostenible: http:// hidrologiasostenible.com/sustainable-urban-drainage-systems-suds/

Hydrolink Technologies (2014) Hydrolink technologies. Retrieved from Hydrolink Technologies: http://hydrolink.co.ke/reverse-osmosis-systems

Kenya Data Portal (2019) Kenya data portal. Retrieved from Kenya Data Portal: https://kenya. opendataforafrica.org/

Matos JS (2003) Aspectos Históricos a Actuais da Evolução da Drenagem de Águas Residuais em Meio Urbano. Revista Engenharia Civil, Lisboa

Mays LW (2001) Stormwater collection systems design handbook. McGraw Hill Professional, New York

National parks Association (n.d.) National parks association of NSW. Retrieved from National Parks Association: http://www.bushwalking101.org/recognising-topographic-features/

National Research Council (2002) Riparian areas: functions and strategies for management. Consensus Study Report. https://doi.org/10.17226/10327

Ogwu M (2019) Towards sustainable development in Africa: the challenge of urbanization and climate change adaptation. (P. a. Cobbinah, Ed.) The geography of climate change adaptation in Urban Africa. pp. 29-55. Retrieved from https://doi.org/10.1007/978-3-030-04873-0_2

Poleto C, Tassi R (2012) Sustainable urban drainage systems. Federal University of Technology, Brazil

Reed B (2004) Sustainable urban Drainage in Low-income Countries. Water, Engineering and Development Centre. Loughborough University Leicestershire. Loughborough University, UK

Taylor RG, Koussis AD, Tindimugaya C (2009) Groundwater and climate in Africa. Hydrological Science Journal 655-664. https://doi.org/10.1623/hysj.54.4.655

The Ocean Portal Team (2018) Ocean portal. Retrieved from Ocean Portal: https://ocean.si.edu/ through-time/ancient-seas/sea-level-rise

The Renewable Energy Hub UK (2018) The renewable energy hub UK. Retrieved from The Renewable Energy Hub UK Website: https://www.renewableenergyhub.co.uk/main/rainwaterharvesting-information/types-of-rainwater-harvesting/

The United Nations-Water (2015) Water for a sustainble world. United Nations Educational, Scientific and Cultural, de Fontenoy 
Tim II (2008) Trabalho de Integralização Multidisciplinar II. Termo de Referência

UN Environment Programme (2020) UN environment programme. Retrieved from UN Environment Programme: https://www.unenvironment.org/regions/africa/regional-initiatives/ responding-climate-change

UN Water (2013) UN - water. Retrieved from UN - Water: https://www.unwater.org/publications/ water-security-infographic/

Viala E (2016) USAID. Retrieved from USAID

Willem VC (2005) Rooftop gardening

Woods BB, Wilson S, Udale-Clarke H, Illiman S, Scott T, Ashley R, Kellagher (2015) The SUDS manual. Construction Industry Research and Information Association, London

World Health Organization (2003) $\mathrm{pH}$ in drinking-water. Guidelines for drinking-water quality, 2. Marketing and Dissemination, World Health Organization. Geneva 27, Switzerland

Open Access This chapter is licensed under the terms of the Creative Commons Attribution 4.0 International License (http://creativecommons.org/licenses/by/4.0/), which permits use, sharing, adaptation, distribution and reproduction in any medium or format, as long as you give appropriate credit to the original author(s) and the source, provide a link to the Creative Commons license and indicate if changes were made.

The images or other third party material in this chapter are included in the chapter's Creative Commons license, unless indicated otherwise in a credit line to the material. If material is not included in the chapter's Creative Commons license and your intended use is not permitted by statutory regulation or exceeds the permitted use, you will need to obtain permission directly from the copyright holder.

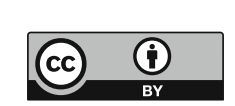

